http://e-journal.stit-islamic-village.ac.id/index.php/JECIES

\title{
TANGGAPAN GURU PAUD TENTANG PEMBERIAN REWARD DAN PENGARUHNYA TERHADAP MOTIVASI BELAJAR DAN PERKEMBANGAN SOSIAL EMOSIONAL ANAK USIA DINI
}

\author{
Tiara Astari, Siti Nur Aisyah, Diah Andika Sari \\ Program Studi Pendidikan Anak Usia Dini Fakultas Ilmu Pendidikan Universitas \\ Muhammadiyah Jakarta \\ Email: \\ tiara.astari@umj.ac.id. aisyahsitinur808@gmail.com, diahmursil@gmail.com
}

Received: 06 Agustus, $2020 . \quad$ Accepted: 11 September, 2020.

Published: 30 September, 2020

\begin{abstract}
The purpose of this study was to determine the responses of PAUD teachers in East Ciputat subdistrict regarding the effect of reward on learning motivation and socio-emotional development of early childhood. The method used is descriptive quantitative with survey techniques, using a questionnaire (questionnaire) using the google form application. Questionnaires (questionnaires) are given to respondents online via WhatsApp, then the collected data will be analyzed. The study population was kindergarten teachers in East Ciputat District, and the number of respondents was 100 people with the sampling technique using simple random sampling. From the data obtained, as many as $80 \%$ of respondents answered that they often gave rewards in the form of good words, namely: good, true, great, cool and smart to children. In addition, as many as 65\% of respondents answered that very often they gave an assessment with a thumbs up, clapping and smiling. It is known that the results of the respondent's answer who gave an assessment in the form of a sticker or stamp were $70 \%$. Meanwhile, $72 \%$ of respondents answered very often that motivation creates a desire to learn in school children. So motivation which serves as a driving force significantly influences learning attitudes in children. Furthermore, 67\% of respondents answered that very often children do learning activities with all their soul and body (willing / not forced, happy, sincere). So based on the theory and the results of the respondents' answers, it can be concluded that motivation is the driving force of the desire to learn in children.
\end{abstract}

Keywords: Reward, Learning Motivation, Social-emotional Development

\begin{abstract}
ABSTRAK
Tujuan dari penlitian ini adalah untuk mengetahui tanggapan guru PAUD se-kecamatan Ciputat Timur mengenai pengaruh reward terhadap motivasi belajar dan perkembangan sosial-emosional anak usia dini. Metode yang digunakan adalah kuantitatif deskriptif dengan teknik survei, menggunakan kuesioner (angket) menggunakan aplikasi google form. Kuesioner (angket) diberikan kepada responden secara online melalui whatsapp, selanjutnya data yang terbimpun akan dianalisis. Populasi penelitian adalah guru taman kanak-kanak se-Kecamatan Ciputat Timur, dan diperoleh
\end{abstract}


responden berjumlab 100 orang dengan teknik pengambilan sample menggunakan simple random sampling. Dari data yang didapat, sebanyak $80 \%$ responden menjawab sangat sering memberikan reward dalam bentuk kata-kata yang baik, yaitu: bagus, betul, bebat, keren dan pintar kepada anak. Selain itu sebanyak 65\% responden menjawab sangat sering memberikan penilaian dengan acungan jempol, tepuk tangan dan senyuman. Diketabui hasil jawaban responden yang memberikan penilaian berupa stiker atau stempel sebanyak. 70\%. Sedangkan terdapat $72 \%$ responden menjawab sangat sering bahwa motivasi menimbulkan keinginan untuk belajar pada anak disekolah. Jadi motivasi yang berfungsi sebagai pendorong ini secara signifikan mempengarubi sikap belajar pada anak. Selanjutnya, ada 67\% responden menjawab sangat sering anak melakukan aktivitas belajar dengan segenap jiwa dan raga (relal tidak terpaksa, senang, ikblas). Jadi berdasarkan teori dan hasil jawaban responden, dapat disimpulkan bahwa motivasi sebagai penggerak keinginan belajar pada anak.

Kata Kunci: Reward, Motivasi Belajar, Perkembangan Sosial-emosional

\section{PENDAHULUAN}

Menyadari akan pentingnya kehidupan pada masa awal anak dengan berbagai pengaruhnya yang berkaitan dengan diterimanya rangsangan (stimulus) dan perlakuan yang diberikan kepada anak. Lingkungan yang memberikan dukungan positif akan menghasilkan anak-anak yang berkualitas unggul di masa mendatang.

Anak usia dini sangat senang apabila mendapatkan kata pujian ataupun reward atas apa yang sudah anak lakukan di sekolah. Walaupun terkadang dalam melakukan kegiatan anak belum berhasil, guru tetap harus mendorong semangat anak dengan memberi pujian atau reward dengan kasih dan sayang. Pujian yang wajar atau reward yang diberikan dengan tepat mempunyai peranan penting bagi anak disekolah. Dengan menggunakan banyak kata pujian dan penghargaan yang mendorong semangat anak, maka guru akan melihat perkembangan mengembirakan dalam kehidupan anak, dan anak akan selalu berada dalam kehidupan yang menyenangkan (Santi Danar, 2009 : 113).

Seorang anak senang dipuji atas hasil pekerjaan yang telah diselesaikan. Pujian yang telah diberikan, guru akan memberikan semangat bagi anak. Anak didik akan lebih bersemangat belajar bila hasil pekerjaannya dipuji dan diperhatikan oleh guru. Pujian harus diberikan secara merata kepada anak didik, bukan hanya yang cantik ataupun pintar tetapi kepada anak didik yang benar-benar melakukan kegiatan bermain sambil belajar disekolah dengan baik. Dengan begitu akan memotivasi belajarnya dan memotivasi teman-teman di sekolah untuk mengikutinya (Bahri, 2011 : 164).

Kehidupan pada masa anak dengan berbagai pengaruhnya adalah masa kehidupan yang sangat penting khususnya berkaitan dengan diterimanya rangsangan (stimulus) dan perlakuan dari lingkungan hidupnya. Kehidupan pada masa anak yang merupakan suatu periode yang disebut sebagai periode 
kritis ataupun periode sensitif dimana kualitas perangsangan harus diatur sebaik - baiknya, tentunya memerlukan intervensi yang baik dari guru maupun orang tua (Mutiah, $2010: 3$ ).

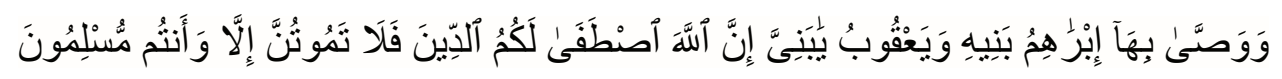

"Dan Ibrahim telah mewasiatkan ucapan itu kepada anak-anaknya, demikian pula Ya'qub. (Ibrabim berkata): "Hai anak- anakeku! Sesunggubnya Allab telah memilih agama ini bagimu, Maka janganlah kamu mati kecuali dalam memeluk agama Islam" (Q.S. Al-Baqarah: 132).

Reward akan memberikan dampak positif pada diri anak. Reward akan memotivasi anak untuk menjadi yang lebih baik, karena reward hanya diberikan kepada anak didik yang mengikuti aturan pembelajaran ataupun permainan di sekolah sehingga bertujuan agar anak didik melakukannya secara terus menerus, meningkatkan semangat dan menjadi contoh bagi teman - teman yang lain di sekolah. Reward merupakan bentuk motivasi bagi anak untuk meningkatkan motivasi belajar.

Reward adalah ganjaran yang bersifat dan berfungsi untuk mempertahankan perilaku positif yang diberikan kepada anak sebagai alat untuk memperkuat perilaku yang diharapkan. Selama dalam periode pendidikan anak usia dini, reward sering digunakan sebagai konsekuensi menyenangkan yang bertujuan membentuk suatu kebiasaan baik yang sesuai dengan norma agama dan norma sosial tempat dimana anak tinggal dan melakukan beragam aktivitas sosialnya. Ada bentuk yang sifatnya verbal dan non-verbal. Contohnya: ketika anak berperilaku baik atau sesuai harapan, maka guru disarankan untuk memberikan pujian objektif (tanpa berlebihan atau sekedar basa-basi) pujian yang dimaksud adalah dengan memberikan kata-kata positif yang berisi motivasi kepada anak, sehingga perilaku yang ingin diperkuat/dipertahankan dapat menetap secara permanen. Sedangkan reward non-verbal berbentuk ekspresi tubuh/simbol gerakan tubuh yang secara umum diberikan sebagai tanda kesetujuan yang dipahami oleh masyarakat umum disekitar lingkungan hidup anak. Ini diberikan melalui acungan jempol, senyum setuju, tepuk tangan, tepukan di pundak, atau usapan di kepala sebagai ganti dari pujian. Kedua hal ini dipercaya sebagai reward yang menyenangkan anak dan mampu memperkuat perilaku positif yang diharapkan sebagai tujuan dalam pendidikan anak usia dini.

Sebagaimana dikutip dari Q.S. An Nisa 4:9 dan Q.S. Al Zalzalah: 7-8:

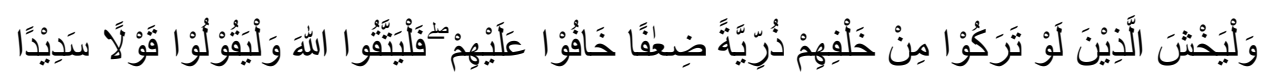

JECIES: Journal of Early Childhood Islamic Education Study

Vol. 01, Nomor 02, September 2020 
"Dan hendaklah takut kepada Allah orang-orang yang seandainya meninggalkan dibelakang mereka anak-anak yang lemah, yang mereka khawatir terbadap (kesejabteraan) mereka. Oleh sebab itu bendaklah mereka bertakwa kepada Allah dan bendaklah mereka mengucapkan perkataan yang benar". (Q.S. An Nisa 4:9)

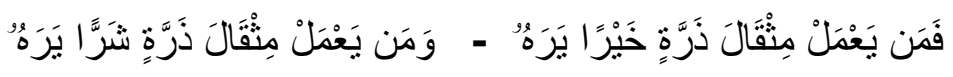

"Barangsiapa yang melakukan kebaikan seberat dzarrah pun, niscaya dia akan melihat (balasannya), dan barangsiapa yang melakukan kejahatan seberat dzarrah pun, niscaya dia akan melihat balasannya”. (Q.S. Al Zalzalah: 7-8)

Berdasarkan ayat di atas, maka dapat dipahami bahwa pemberian reward merupakan alat yang dapat digunakan untuk memotivasi anak manusia dalam berbuat kebaikan. Tindakan memotivasi akan lebih dapat berhasil jika memiliki tujuan yang jelas. Oleh karena itu, setiap pendidik seharusnya mengetahui kebutuhan anak sesuai dengan tahap perkembangannya.

Berdasarkan hasil wawancara pra penelitian kepada beberapa orang guru TK, mengatakan bahwa reward sangat berpengaruh tehadap motivasi belajar anak di sekolah. Guru memberikan reward kepada anak saat pulang sekolah, tetapi reward yang diberikan kepada masing-masing anak berbedabeda. Anak yang mengikuti kegiatan bermain sambil belajar dengan baik akan mendapatkan stiker smile, tapi anak yang mengikuti kegiatan bermain sambil belajar dengan tidak tertib akan mendapatkan stiker sedih. Dengan ini, anak yang mendapatkan stiker sedih termotivasi untuk mendapatkan stiker smile dari guru dan anak-anak akan termotivasi untuk berprilaku positif.

Selain itu pemberian reward dapat berupa kata -kata pujian, senyuman, tepukan tangan atau sesuatu yang menyenangkan bagi anak sehingga anak akan lebih senang dan termotivasi dalam mengikuti kegiatan bermain sambil belajar yang menyenangkan. Reward merupakan suatu hal yang disenangi anak. Guru membutuhkan penerapan reward dalam belajar mengajar di sekolah untuk meningkatkan motivasi belajar anak.

Maksud dari guru memberi reward kepada anak didik adalah supaya anak menjadi lebih giat lagi dalam mengikuti kegiatan bermain sambil belajar yang menyenangkan di sekolah. Hal ini didukung dengan hasil penelitian yang menunjukkan bahwa reward dapat mempengaruhi kemandirian belajar dan pihak yang terlibat yaitu guru dan orangtua harus memperhatikan hal ini agar pemberian reward tidak berdampak negative bagi anak selama proses mengembangkan potensi anak (Richa Puspitasari, 2015:55) 
Penelitian sebelumnya tentang reward menjelaskan bahwa guru kelas membuat rancangan reward dengan mempersiapkan hal-hal yang diperlukan khususnya reward yang berupa star pocket, hadiah dan stempel, serta merumuskan tujuan dalam memberikan reward pada anak. Jenis reward verbal yang yang diberikan oleh guru di TK Islam Al-Azhar 35 Surabaya berupa katakata bagus, good, anak hebat, Alhamdulillah, pintar. Reward non verbal yang diberikan adalah pemberian stempel di tangan anak, bintang penghargaan yang kemudian dikumpulkan di starpocket kelas yang kemudian akan dihitung jumlah bintang masing-masing anak dan yang memiliki bintang terbanyak akan mendapatkan hadiah yang bersifat edukatif dari guru kelas, seperti memberikan hasil karya anak untuk dibawa pulang kerumah, memasang hasil karya anak di papan kreasi dan di sekitar ruangan sekolah, ada juga reward berupa dapat melakukan beberapa kegiatan terlebih dahulu.

Rewward verbal dan non verbal tidak diberikan secara terus-menerus. Hanya diberikan kepada anak yang benar-benar menunjukkan kecenderungan perubahan perilaku maupun minat belajarnya dengan lebih baik dari pada sebelumnya. Hasil pemberian reward yang diberikan oleh guru kelas di TK Islam Al-Azhar 35 Surabaya dapat meningkatkan motivasi belajar anak.

Menurut Rosyid Zaiful (2018 : 43) reward adalah salah satu alat pendidikan, jadi dengan sendirinya maksud reward (ganjaran) itu adalah sebagai alat untuk mendidik anak - anak supaya anak dapat merasa senang karena perbuatan atau pekerjaanya mendapat penghargaan. Umumnya anak mengetahui bahwa pekerjaan atau perbuatannya yang menyebabkan mendapat reward.

Selanjutnya pendidik bermaksud juga supaya dengan reward anak lebih giat lagi usahanya untuk memperbaiki atau mempertinggi prestasi yang telah dapat dicapainya. Dengan kata lain anak menjadi lebih tekun dalam belajar dengan kemauan untuk bekerja dan berbuat hal yang lebih baik lagi yang dibuktikan dengan prestasi belajar. Berikanlah pujian, reward, ganjaran atau hadiah untuk membangkitkan motivasi belajar. Guru dapat melakukannya melalui pemberiah pujian. Pujian akan membangkitkan semangat anak dalam mengikuti kegiatan bermain seraya belajar yang menyenangkan disekolah, tetapi sebaliknya apabila kritik, cacian dan kemarahan akan membunuh motivasi belajar anak (Sukmadinata, $2011: 72$ ).

Maria J. Wantah (2005 : 165) mengemukakan fungsi dari pemberian reward yaitu sebagai berikut :

1) Penghargaan mempunyai nilai mendidik. Penghargaan yang diberikan kepada anak menunjukkan bahwa perilaku yang dilakukan oleh anak di sekolah adalah perilaku yang positif. Apabila anak mendapatkan sesuatu penghargaan, maka anak akan memperoleh kepuasan, dari kepuasan itu 
akan mempertahankan, memperkuat dan mengembangkan tingkah laku yang positif atau tingkah laku yang baik.

2) Penghargaan berfungsi sebagai motivasi pada anak untuk mengulangi dan mempertahankan perilaku yang positif. Apabila anak bertingkah laku sesuai dengan yang diharapkan secara terus menerus, ketika perilaku tersebut dihargai, maka anak akan merasa bangga terhadap dirinya sendiri. Kebanggaan itu akan membuat anak untuk terus mengulangi bahkan meningkatkan kualitas perilaku tersebut.

Sebagai metode pembelajaran, reward akan sangat ideal dan strategis jika digunakan sesuai dengan prinsip-prinsip belajar untuk merangsang belajar dalam rangka mengembangkan potensi anak didik. Pemberian hadiah dan pujian merupakan reward atas perilaku baik yang dilakukan anak. hal ini sangat diperlukan dalam hubungannya dengan motivasi dan penerapan disiplin pada anak (Sardiman, 2014:81).

Reward memiliki tiga fungsi penting dalam mengajari anak untuk berprilaku yang disetujui secara sosial, fungsi pertama ialah memiliki nilai pendidikan, yang kedua pemberian reward harus menjadi motivasi bagi anak untuk mengulangi prilaku yang memang diharapkan oleh masyarakat. Fungsi ketiga ialah untuk emmperkuat perilaku yang disetujui secara sosial dan tiadanya reward melemahkan keinginan untuk mengulangi perilaku tersebut. Oleh karenanya, maka reward sebagai metode dalam pendidikan adalah upaya pengimplementasikan rencana yang dilakukan oleh pendidik terhadap peserta didik untuk memberikan penghargaan terhadap peserta didiknya karena peserta didik tersebut telah melakukan hal - hal yang baik atau mencapai sebuah tahap perkembangan tertentu atau target tertentu.

Selanjutnya, Thoifur (2008:61) berpendapat bahwa reward sebagai metode penghargaan. Metode ini yaitu memberikan hadiah pada anak didik,baik yang berprestasi akademik ataupun anak didik yang berperilaku baik. Penghargaan hadiah dianggap sebagai media pengajaran yang preventif dan representatif untuk membuat senang dan menjadi motivasi belajar anak didik. Pemberian hadia harus didahulukan dari pada hukuman, karena pemberian hadiah lebih baik pengaruhnya dalam motivasi belajar.

Kelebihan dari metode penghargaan adalah mampu mencipatakan peserta didik untuk melakukan hal-hal positif dan progresif, serta dapat menjadikan motivasi siswa lainnya dalam semangat belajar. Kekurangan dari metode ini jika guru berlebihan dalam melakukannya yaitu siswa merasa dirinya lebih baik dari teman-temannya. Jadi metode penghargaan ini harus dilakukan dengan baik dan benar.

Dijelaskan lebih lanjut oleh Sardiman (2014:92) bentuk reward dapat dibedakan menjadi, yaitu : 
1) Pemberian angka atau nilai. Angka sebagai simbol kegiatan belajar, angka yang dimaksud adalah nilai tambahan yang diberikan kepada anak yang mengikuti kegiatan belajar dengan baik.

2) Pemberian hadiah. Bentuk hadiah yang dimaksud adalah pemberian berupa barang. Seperti hadiah yang terdiri dari alaat-alat keperluan sekolah yaitu pensil, penggaris, buku, dan lain sebagainya.

3) Pemberian pujian. Pemberian pujian akan memupuk suasana yang menyenangkan dan membangkitkan semangat belajar.

Berdasarkan hal-hal berikut diatas, dalam penerapannya memilih bentuk macam - macam reward yang cocok untuk anak dan disesuaikan dengan situasi yang tepat.

Djamarah (2011:152) berpendapat bahwa motivasi adalah gejala psikologis yang timbul pada diri seseorang dalam bentuk dorongan secara sadar atau tidak sadar untuk melakukan suatu tindakan dengan tujuan tertentu. Motivasi mempunyai peranan penting dalam aktivitas belajar. Motivasi pujian lebih baik dari pada motivasi dengan hukuman. Motivasi berupa pujian dapat meningkatkan semangat belajar anak. Oleh karena itu motivasi pujian harus diberikan pada tempat dan kondisi yang tepat.

Pujian yang diberikan pada waktu yang tepat dapat dijadikan sebagai motivasi bagi anak. Pujian adalah bentuk reinforcement yang positif dan merupakan motivasi yang sangat baik. Guru dapat memberikan pujian untuk memuji keberhasilan anak didik dalam mengerjakan atau mengikuti aturan dalam belajar dan bermain di sekolah. Pujian diberikan sesuai dengan apa yang anak didik lakukan. Sedangkan menurut Hamalik Oemar (2010: 173) motivasi dapat berupa dorongan - dorongan dasar atau internal dan insentif di luar diri individu atau hadiah. Sebagai suatu masalah dalam kelas, motivasi adalah proses membangkitkan, mempertahankan, dan mengontrol minat - minat. Menurut McDonald motivasi adalah suatu perubahan energi di dalam pribadi seseorang yang ditandai dengan timbulnya efektif dan reaksi untuk mencapai tujuan. Guru sering kali menggunakan insentif untuk memberi motivasi kepada siswa untuk mencapai tujuan pengajaran. Insentif akan bermanfaat jika mengandung tujuan yang akan memberikan kepuasan terhadap kebutuhan psikologis anak, itu sebabnya guru harus kreatif dan imajinatif dalam menyediakan insentif yang tepat.

Skinner, dalam buku Educational Psychology : The Teaching-Learning Process, Barlow (1995) berpendapat bahwa belajar adalah suatu proses adaptasi atau penyesuaian tingkah laku yang berlangsung secara progresif. B.F Skinner percaya bahwa proses adaptasi tersebut akan mendatangan hasil yang optimal apabila diberi penguat (reinforcer). Sedangkan Hintzman berpendapat bahwa belajar adalah perubahan yang terjadi dalam diri organisme, disebabkan oleh pengalaman yang dapat merubah tingkah laku tersebut. Perubahan yang 
ditimbulkan oleh pengalaman tersebut dapat dikatakan belajar apabilah dapat mempengaruhi organisme (Syah, 2003 : 65).

Menurut teori behavioristik, belajar adalah suatu perubahan tingkah laku sebagai akibat adanya intraksi stimulus dan respon. Menurut teori behavioristik bukan hanya stimulus dan respon, tapi faktor penguatan (reinforcement) juga penting. Penguatan adalah semua hal yang dapat memperkuat respon, bila penguatan ditambahkan (positive reinforcement) maka respon akan semakin kuat. Jadi penguatan merupakan suatu bentuk stimulus yang penting diberikan untuk menimbulkan adanya respons (Robert, 2011 : 174).

Terkait dengan perkembangan Perkembangan sosial dan emosional menjadi perhatian penting dalam pendidikan anak usia dini. The Center on the Social Emotional Foundation for Early Learning (CSEFEL) mendefinisikan perkembangan sosial-emosional adalah perkembangan kapasitas seorang anak sejak lahir sampai usia 5 tahun untuk membentuk pribadi yang dewasa dan aman dalam berelasi dengan sebaya melalui pengalaman, regulasi dan mengekspresikan emosi dalam lingkungan sosialnya dan sesuai dengan budayanya, mengeksplorasi lingkungan dan belajar yang seluruhnya dalam konteks keluarga, masyarakat, dan budaya (Yates Tweety, dkk, 2008:2).

Menurut Merita Shala (2013:787), bahwa perkembangan sosial dan emosional pada anak terkait dengan apa yang dirasakan anak tentang dirinya (contoh: percaya diri, ketakutan, rasa ingin tahu untuk belajar, perasaan bangga terhadap budayanya, takut melakukan kesalahan), cara berperilaku (contoh: bertengkar, mudah marah, mampu mengatasi konflik), dan cara mereka menjalin hubungan dengan orang lain khusunya dengan orang terdekat (contoh: keluarga, orangtua, guru, dan teman).

Hasil penelitian Durak \& Greenberg menunjukkan bahwa perilaku positif termasuk dalam peningkatan keterampilan sosial-emosional, sikap yang mengarah pada hubungan interpersonal, dan perilaku di kelas. Sedangkan perilaku negatif termasuk dalam mengurangi masalah perilaku dan tekanan emosional (Lawrence T.Lam \& Emmy M.Y Wong, 2017: 3).

Kemampuan sosial-emosional merupakan dua sisi mata uang yang saling mempengaruhi. Sinyal emosi yang ada dalam diri setiap anak diyakini memiliki pengaruh kuat terhadap caranya berperilaku terhadap orang lain. Demikian sebaliknya, reaksi emosi ditimbulkan dipengaruhi oleh perilaku orang lain. Keberhasilan pengelolaan emosi akan mempengaruhi kesuksesan anak dalam menjalin hubungan sosial dengan orang lain. Anak belajar mengendalikan dan mengelola emosinya bersamaan dengan pengalamannya berinteraksi dengan orang disekitarnya, yakni keluarga, teman sebaya dan guru.

Cohen Oser \& Quigley berpendapat bahwa perkembangan sosialemosioal pada anak usia dini meliputi: a. bentuk kedekatan dan rasa aman dari 
orang dewasa dan teman sebaya, b. pengalaman, mengelola dan mengekspresikan emosi, c. mengeksplorasi lingkungaan dan belajar tentang keluarga, komunitas, dan budayanya (Deborah Carter, 2016:13).

Selanjutnya Denham dan Saarni (Celene E.Domitrovich, dkk, 2007:69), menyebutkan bahwa kompetensi sosial-emosional pada anak usia dini bervariasi, dimana komposisi dari keterampilan dan pengetahuan terintegrasi dalam emosi, kognitif dan domain perilaku perkembangan. Contohnya, kompetensi emosional ditandai dengan kesadaran akan ekspresi perasaan, identifikasi emosi, tahu akan situasi, dan regulasi emosi.

Sedangkan Pearson \& Rodgers menyebutnya sebagai perkembangan personal dan sosial. Perkembangan ini adalah mencakup perasaan anak terhadap diri sendiri dan hubungan mereka dengan orang lain. Hal ini mengacu pada perilaku dan respon anak untuk bermain dan berkegiatan serta kedekatan mereka dengan anggota keluarga, pengasuh, guru, dan teman-teman. Peran jender, kemandirian, moralitas, kepercayaan dan penerimaan terhadap peraturan merupakan aspek dasar perkembangan ini (Allen Marots, 2010:31).

Berdasarkan pendapat para ahli diatas, maka dapat disimpulkan bahwa kemampuan sosial-emosional anak usia dini adalah ketercapaian dalam melakukan tugas-tugas perkembangan emosional yang dipengaruhi oleh interaksi anak dengan lingkungan. Interaksi ini terjadi bukan saja dengan orangtua namun bersama guru PAUD. Oleh sebab itu, perlakuan guru PAUD secara jelas dapat mempengaruhi perkembangan sosial-emosional anak, dimana reward menjadi salah satu cara yang digunakan oleh guru untuk memberikan penghargaan atas diri anak seutuhnya, dimana dalam penelitian sebelumnya menunjukkan bahwa reward secara signifikan berpengaruh pada motivasi belajar serta kemandirian anak. Sehingga dapat dikatakan bahwa reward secara tidak langsung dapat mempengaruhi perkembangan sosialemosional anak, diantaranya memperkuat perilaku positif saat berinteraksi dengan orang lain.

\section{METODE}

Penelitian ini menggunakan pendekatan kuantitatif deskriptif dengan teknik survey. Pengumpulan data menggunakan kuesioner yang berisi pernyataan-pernyataan yang disusun menggunakan aplikasi Google Form dan didistribusikan kepada responden melalui aplikasi media sosial whatsapp. Rumusan masalah dari penelitian ini adalah: 1) Apakah ada pengaruh reward terhadap motivasi dan perkembangan sosio-emosional anak taman kanakkanak se-kecamatan Ciputat Timur? 2) Bagaimana penerapan reward terhadap motivasi belajar dan perkembangan sosio-emosional anak taman kanak-kanak? Secara praktis survey ini akan memberikan informasi tentang pengaruh reward terhadap motivasi belajar dan perkembangan sosio-emosional anak taman 
kanak-kanak se-kecamatan ciputan timur. Secara Teoritis, memberikan rekomendasi kepada guru PAUD dan orangtua tentang pentingnya reward dan teknik memberikan reward berdasarkan pengalaman guru PAUD sekecamatan Ciputat Timur..

\section{HASIL DAN PEMBAHASAN}

Sekolah yang digunakan sebagai populasi penelitian adalah Taman Kanak-kanak se Kecamatan Ciputat Timur, Kabupaten Tangerang Selatan, Provinsi Banten. Dalam penelitian ini menggunakan teknik random sampling, dimana pengambilan anggota sampel dari populasi dilakukan secara acak tanpa memperlihatkan strata yang ada dalam populasi itu.

Sebanyak 100 sekolah taman kanak-kanak dikecamatan Ciputat Timur yang terdiri dari 6 Kelurahan menjadi sampel dalam penelitian ini. Responden dalam penelitian ini adalah perwakilan satu guru dari masing - masing sekolah taman kanak-kanak se-kecamatan Ciputat Timur yang menjadi sampel.

Responden dalam penelitian ini adalah perwakilan satu guru dari masing-masing sekolah taman kanak - kanak dikecamatan Ciputat Timur yang menjadi sampel. Adapun rincian responden dari 100 sampel sekolah, dapat dilihat pada gambar dibawah ini :

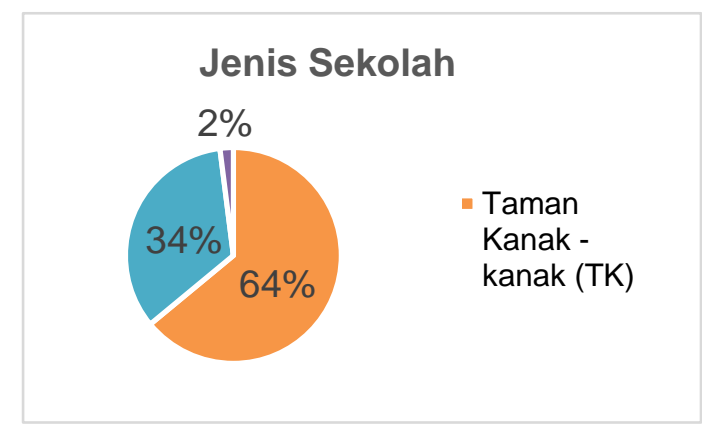

Gambar 1. Distribusi Frekuensi Jenis Sekolah Taman Kanak-kanak Se-Kecamatan Ciputat Timur

Berdasarkan gambar diatas, diketahui bahwa satuan pendidikan anak usia dini dikecamatan Ciputat timur terdiri dari, 64 taman kanak-kanak (64\%), diikuti 34 satuan PAUD Sejenis (34\%) dan 2 kelompok bermain (2\%).

Berdasarkan gambar diatas, dalam penelitian diketahui bahwa jenis kelamin guru dari 100 sekolah diKecamatan Ciputat Timur mayoritas adalah guru perempuan. Karena terdapat 99 guru perempuan (99\%) dan 1 guru lakilaki (1\%) yang mengisi kuesioner (angket) ini. 


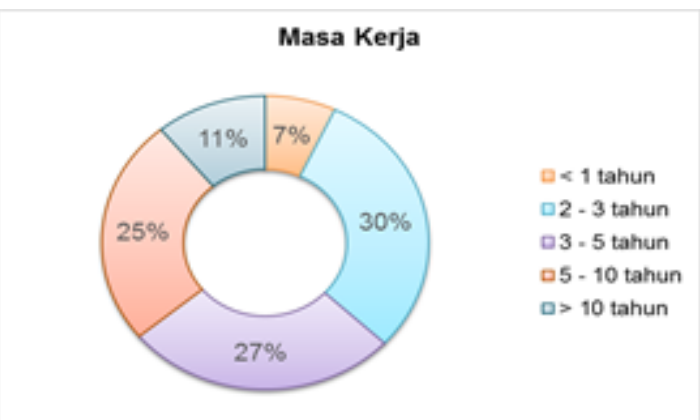

Gambar 2. Distribusi Frekuensi Masa Kerja Guru Sekolah Taman Kanakkanak se-Kecamatan Ciputat Timur

Berdasarkan gambar diatas, dapat diketahui masa kerja guru di Taman kanak-kanak Kecamatan Ciputat Timur yang berada pada rentang waktu kurang dari 1 tahun, 2 sampai 3 tahun, 3 sampai 5 tahun, 5 sampai 10 tahun dan lebih dari 10 tahun. Dari hasil penelitian ini dapat dikatakan guru yang bekerja 2-3 tahun sebanyak (30\%), kemudian guru yang bekerja 3-5 tahun sebanyak (27\%), sedangkan guru yang bekerja 5-10 tahun sebanyak (25\%), selanjutnya guru yang bekerja lebih dari 10 tahun sebanyak (11\%) dan guru yang bekerja kurang dari 1 tahun sebanyak (7\%).

Berikutnya diketahui status pendidikan guru taman kanak-kanak Kecamatan Ciputat Timur yang terbanyak adalah S1 PAUD sebanyak (39\%), diikuti S1 Pendidikan non PAUD sebanyak (33\%), SMA sederajat sebanyak (17\%), selanjutnya S1 non pendidikan sebanyak (7\%) dan pendidikan D3 sebanyak (4\%). Sehingga dapat dikatakan pendidikan terakhir guru yang menjadi sampel dalam penelitian ini mayoritas lulusan S1 PAUD.

Hasil penelitian terlihat jenis sekolah paling banyak yaitu taman kanakkanak sebanyak 64\%, satuan PAUD sejenis sebanyak 34\% dan kelompok bermain 2\%. Jenis kelamin guru mayoritas perempuan yaitu sebanyak $99 \%$. Status pendidikan terakhir guru taman kanak-kanak dikecamatan Ciputat Timur paling banyak yaitu guru berpendidikan S1 PAUD sebanyak 39\%, selanjutnya guru lulusan S1 pendidikan non PAUD sebanyak 33\%, pendidikan guru yang masih lulusan SMA sederajat ada 17\%, guru yang sarjana non pendidikan sebanyak $7 \%$ dan guru pendidikan diploma ada 4\%. Dengan latar belakang pendidikan guru terbanyak yaitu guru sarjana pendidikan PAUD dan sarjana pendidikan non PAUD. 
Menurut Purwanto (2011 : 182) reward adalah salah satu alat pendidikan. Alat untuk mendidik anak - anak supaya anak dapat merasa senang karena perbuatan atau pekerjaan - pekerjaannya mendapat penghargaan. Melalui reward, anak akan lebih termotivasi mengulangi perilaku yang positif. Kazhim (2011 : 85) berpendapat bahwa reward merupakan efek yang dilakukan pendidik terhadap anak didiknya, sehingga dapat menimbulkan perilaku anak didik yang positif. Sehingga dapat kita lihat sebanyak $67 \%$ responden menjawab sangat sering memberikan pengakuan terhadap keberadaan anak didik. Pengakuan yang dimakusud adalah pengakuan terhadap anak didik supaya mereka merasa dianggap keberadaannya. Sebanyak $70 \%$ guru sering membangun hubungan yang positif dengan anak. Dengan begitu maka anak didik dan pendidik akan semakin.

Analysis dekat dan menjadikan proses belajar menjadi menyenangkan. Bentuk reward dapat dilakukan dengan memberikan kata-kata yang baik seperti : bagus, betul, hebat, keren dan yang lainnya, adalah isyarat seorang pendidik yang menunjukkan sesuatu yang benar atas pekerjaan atau kegiatan yang dilakukan anak didik, dengan itu anak didik akan termotivasi untuk terus melakukan hal-hal yang baik dan benar (Khazim, 2011 :85). Dari data yang didapat, sebanyak $80 \%$ responden menjawab sangat sering memberikan katakata yang baik seperti : bagus, betul, hebat, keren dan pintar kepada anak disekolah. Selain itu sebanyak $65 \%$ responden menjawab sangat sering memberikan penilaian dengan acungan jempol, tepuk tangan dan senyuman. Diketahui hasil jawaban responden yang memberikan penilaian berupa stiker atau stempel sebanyak $70 \%$.

Selanjutnya, dikatakan bahwa reward dapat dilakukan dengan pemberian hadiah. Bentuk hadiah yang dimaksud adalah pemberian berupa barang. Seperti hadiah yang terdiri dari alat-alat keperluan sekolah. Dari data yang didapat, diketahui hanya $21 \%$ responden yang menjawab sangat sering memberikan hadiah kepada anak. sedangkan 37\% responden menyatakan kadang-kadang. jadi masih banyak guru yang tidak menggunakan pemberian hadiah sebagai reward untuk anak disekolah.

Menurut Sardiman (2014:92) Pemberian pujian akan memupuk suasana yang menyenangkan dan membangkitkan semangat belajar anak. Dari data berikut didapati sebanyak $71 \%$ responden menjawab sangat sering memberikan pujian ketika anak mampu menyelesaikan kegiatan bermain dan belajar disekolah. Hamzah Uno (dalam Sumantri, 2015 : 378) menjelaskan bahwa motivasi belajar adalah dorongan dan kekuatan dalam diri seseorang untuk melakukan tujuan tertentu yang ingin dicapainya. Dengan kata lain motivasi belajar dapat diartikan sebagai suatu dorongan yang ada pada diri seseorang. Terbukti dari data yang diperoleh sebanyak $72 \%$ responden menjawab sangat sering bahwa motivasi menimbulkan keinginan untuk belajar 
pada anak disekolah. Jadi motivasi yang berfungsi sebagai pendorong ini mempengaruhi sikap yang seharusnya anak didik ambil dalam rangka belajar.

Motivasi sebagai penggerak psikologis yang melahirkan sikap terhadap anak didik, kemudian terjelma dalam bentuk gerakan psikofisik. Disini anak didik dapat melakukan aktivitas belajar dengan segenap jiwa dan raga (Djamarah, 2011 : 57). Sesuai dengan data yang diperoleh sebanyak 67\% responden menjawab sangat sering anak melakukan aktivitas belajar dengan segenap jiwa dan raga (rela/tidak terpaksa, senang, ikhlas). Jadi berdasarkan teori dan hasil jawaban responden, dapat disimpulkan bahwa motivasi sebagai penggerak keinginan belajar anak. Motivasi Sebagai pengarah, artinya mengarahkan perbuatan kepada pencapaian tujuan yang diinginkan anak didik. Data yang diperoleh sebanyak $34 \%$ responden meyatakan sangat sering dan sebanyak 53\% responden menyatakan sering mengarahkan anak didik untuk mencapai tujuan yang diinginkan (Hamalik Oemar, 2010:175).

\section{SIMPULAN}

Berdasarkan data yang diperoleh, reward mempunyai pengaruh kepada motivasi belajar anak disekolah. Dapat disimpulkan dengan diterapkannya reward disekolah, akan menimbulkan keinginan anak untuk belajar dan bermain yang menyenangkan dengan sungguh-sungguh, tertib dan bertanggung jawab, dimana perilaku ini mencerminkan indikator perkembangan sosial emosional anak.

Adapun saran terkait yang dapat diberikan pada penelitian ini adalah, sebagai berikut :

1. Peran guru sangat penting dalam meningkatkan motivasi belajar anak disekolah, oleh karena itu guru harus mempunyai cara-cara tertentu untuk meningkatkan motivasi belajar anak.

2. Guru diharapkan selalu menerapkan reward untuk meningkatkan motivasi belajar anak yang secara tidak langsung dapat mengembangkan sosialemosionalnya di taman kanak-kanak.

3. Reward yang diberikan kepada anak didik harus menarik dan bersifat positif kearah penguatan perilaku yang sesuai dengan tugas-tugas perkembangan sosial dan kematangan emosionalnya.

\section{UCAPAN TERIMA KASIH}

Peneliti mengucapkan terima kasih kepada Fakultas Ilmu Pendidikan Universitas Muhammadiyah Jakarta atas dukungan pendanaan dan fasilitas yang telah diberikan selama proses penelitian, sebagaimana tercantum dalam surat kontrak penelitian, nomor kontrak 01/F.8-UMJ/V/2020. 


\section{DAFTAR PUSTAKA}

Allen Marots (2010). Profil Perkembangan Anak. PT.Indeks.

Carter Deborah (2016). A Nature-Based Social-Emotional Approach to Supporting Young Children's Holistic Development in Classrooms

With and Without Walls: The Social-Emotional and Environmental Education Development (SEED) Framework.

Domitrovich, Celene E, dkk (2007). Improving Young Children's Social and

Emotional Competence: A Randomized Trial of The Preshool "PATHS" Curriculum. The Journal of Primary Prevention, Vol.28,

No.2, March 2007: Springer Science+Business Media, LLC.

Djamarah, Syaiful Bahri. (2011). Psikologi Belajar. Jakarta : PT Rineka Cipta

Hamalik,Oemar. (2010). Psikologi Belajar dan Mengajar. Bandung : Sinar Baru

Algesindo

Hapsari,Rian Putri. (2013). Studi Tentang Pelaksanaan Pemberian Reward

Dalam Meningkatkan Motivasi Belajar. Jurnal BK Unesa, 4(1). Diunduh dari https://www.neliti.com/publications/249546/studi-tentang-

pelaksanaan-pemberian-reward-dalam-meningkatkan-motivasi-belajar-k

Kazhim, M. N. (2011). Sukses Mendidik. Anak Tanpa Kekerasan. Solo: Samudera Lam, Lawrence T and Wong, Emmy.M.Y (2017). Enhancing Social-emotional Well_Being in Young Children Through Improving Teachers' SocialEmotional Competence and Curriculum Design in Hong Kong. International Journal of Child Care and Education Policy. Springer Open. http://creativecommons.org/licenses/by/4.0/.

Muthia, D. (2010). Psikologi Bermain Anak Usia Dini. Jakarta: Kencana

Richa Puspitasari. (2015). Pengaruh Pemberian Hadiah (Reward) Terhadap

Kemandirian Belajar Anak di TK Tunas Muda Karas Kabupaten Magetan TA 2015/2016. Prosiding Seminar Nasional

Pendidikan,Universitas Sebelas Maret Surakarta dan ISPI Wilayah Jawa Tengah. .

Robert, E. Slavin. (2011). Psikologi Pendidikan Teori dan Praktik. Jakarta : Indeks Rosyid, M. Zaiful. (2018). Reward dan Punishment Dalam Pendidikan. Malang : Literasi Nusantara

Santi, Danar. (2009). Pendidikan Anak Usia Dini. Jakarta: PT Macanan Jaya Cemerlang

Sardiman. (2014). Interaksi Motivasi Belajar Mengajar. Jakarta : PT Raja Grafindo Persada

Shala Merita (2013). The Impact of Preschool Social-Emotional Development on Academic Success of Elementary School Students. Scienticif Research Vol.4, No11, 787-791. http://www.scirp.org/journal/psych. 
Tanggapan Guru PAUD tentang Pemberian Reward dan Pengaruhnya Terhadap Motivasi Belajar dan Perkembangan Sosial Emosional Anak Usia Dini

Sumantri, Syarif Mohamad. (2015). Strategi Pembelajaran. Depok : PT Raja Grafindo Persada

Sukmadinata. (2011). Landasan Psikologi Proses Pendidikan. Yogyakarta : Pustaka Pelajar

Sukmadinata, Nana Syaodih. (2011). Metode Penelitian Pendidikan. Bandung : PT Remaja Rosdakarya

Syah, Muhibin. (2003). Psikologi Belajar. Depok: PT Raja Grafindo Persada.

Uno, B. Hamzah. (2012). Teori Motivasi dan Pengukurannya Analisis di Bidang Pendidikan. Jakarta : Bumi Aksara

Wantah, J. Maria. (2005). Pengembangan Disiplin dan Pembentukan Moral Pada Anak Usia Dini. Jakarta : Departemen Pendidikan Nasional

Wahyudi Setiawan. (2018). Reward and Punishment dalam Perspektif Pendidikan Islam. Jurnal Al-Murabbi Volume 4, Nomor 2, Januari 2018.

Yates Tweety.,et al (2008). Research Synthesis on Screening and Assesing Social-Emotional Cometence. The Center on the Social and Emotional Foundation for Early Learning: Vanderbit University. 